\title{
Hibás kommunikációs panelek perinatalis veszteség esetén
}

\author{
Monostori Dóra $^{1,2}$ - Dombi Edina ${ }^{3,4}$ - Zelena András dr. ${ }^{5,6}$ \\ ${ }^{1}$ Pécsi Tudományegyetem, Egészségtudományi Kar, Egészségtudományi Doktori Iskola, Pécs \\ Szegedi Tudományegyetem, ${ }^{2}$ Egészségtudományi és Szociális Képzési Kar, \\ Preventív Egészségügyi Gondozás Tanszék, \\ ${ }^{3}$ Általános Orvostudományi Kar, Szülészeti és Nőgyógyászati Klinika,

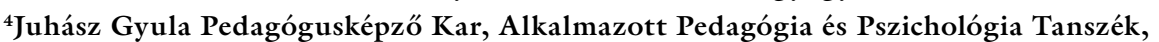 \\ ${ }^{5}$ Általános Orvostudományi Kar, Magatartástudományi Intézet, Szeged \\ ${ }^{6}$ Budapesti Gazdasági Egyetem, Külkereskedelmi Kar, Társadalomtudományi Intézet, Budapest
}

\begin{abstract}
A szülészeti és gyermekintenzív ellátás során prae- és perinatalis veszteségeket átélt, gyermeküket gyászoló szülőkkel a tragédiáról először az ellátóteam tagjai beszélnek. A hazai törvényi szabályozás értelmében a halálhírt csak orvos közölheti. E kommunikációs folyamat rendkívül összetett, és speciális helyzetére igyekszünk rávilágítani egy esetleírás segítségével. Vázoljuk, hogy milyen hibás, esetenként rendkívül helytelen „vigasztalónak” szánt megnyilatkozások kísérik a veszteséget átélt anya és a szakszemélyzet kommunikációját. A családok és hozzátartozók vulnerabilitása tetten érhető ezen időszakban, s a halálhír közlését követő szakaszban a hozzátartozók impulzív reakciói is gyakran észlelhetők. Kifejezetten traumatogén a „nem baj, nemsokára teherbe esik, lehet még gyermeke”-tartalmú, vigaszként szánt mondat. E konkrét esetismertetésen és értelmezési keretein keresztül kívánjuk bemutatni, hogy miként tud hatékony támogatást nyújtani egy speciálisan képzett szakember, melyek lesznek azok a szempontok, amelyek a támaszadás folyamatában preferenciát élveznek. Mind a hazai, mind pedig a nemzetközi szakirodalom összegző megállapításait fókuszba emeljük.
\end{abstract}

Orv Hetil. 2018; 159(12): 1033-1036.

Kulcsszavak: vigasztaló kommunikációs panelek perinatalis veszteségben, empatikus orvos-beteg kommunikáció, gyásztámogatás

\section{Wrong communication panels for perinatal loss}

In the case of obstetrics and intensive child care, the members of the medical team are the first to communicate with mourning parents about their pre- and perinatal loss. According to the national law, only doctors are allowed to report death. Our aim is to emphasize the complexity and specificity of this communication process by presenting a short case study, in which we highlight how improper, incorrect and sometimes misleading this communication can be regardless on the pain of the mourning parents. The mourning period is characterized by the vulnerability of families and very often accompanied with impulsive reactions. Tipical consolatory phrases in the post-mortem communication such as "No problem, you are able to get pregnant again and you will have a child soon!" can be especially traumatogenic. Through the presented case description we would like to emphasize how effective support can be provided by a trained specialist, and what aspects should be taken into consideration. In order to benefit from the supporting communication we collected some national and international guidelines.

Keywords: consolatory communication panels in perinatal loss, empathic physician-patient communication, support in grief

Monostori D, Dombi E, Zelena A. [Wrong communication panels for perinatal loss]. Orv Hetil. 2018; 159(12): 1033-1036.

(Beérkezett: 2017. november 26.; elfogadva: 2017. december 20.) 


\section{Rövidítés}

PTSD = poszttraumás stressz szindróma

Prae- és perinatalis veszteségeket átélt, gyermeküket gyászoló szülőkkel a halálhírközlést követően az ellátóteam tagjai (szülész-nőgyógyász szakorvosok, neonatológusok, szülésznők, szakápolók és asszisztensek) találkoznak a kórházi-klinikai szakaszban. E találkozások általában megelőzik a kórházi osztályok mentálhigiénés munkatársainak, pszichológusainak és gyásztanácsadóinak betegágyhoz érkezését. Egy esetleírás segítségével arra világítunk rá, hogy milyen hibás, esetenként rendkívül helytelen „vigasztalónak” szánt megnyilatkozások kísérik a veszteséget átélt anya és a szakszemélyzet kommunikációját. A családok és hozzátartozók vulnerabilitása tetten érhető ezen időszakban, s a halálhír közlését követô szakaszban a hozzátartozók impulzív reakciói is gyakran észlelhetők. Kifejezetten traumatogén a „nem baj, nemsokára teherbe esik, lehet még gyermeke"-tartalmú, vigaszként szánt mondat. E speciális és rendkívül érzékeny téma honi és nemzetközi szakirodalma széles körü, melyből az alábbiakat emeljük ki: A kommunikáció szerepe az ellátási hibák megelózésében és kezelésében címú tanulmánykötetben [1] Pilling János problémaérzékenyen és értőn világít rá a kommunikációs hibák következményeire, azok megelőzhetőségét részletgazdagon tárgyalja. A magyar szakirodalom bázisának a hazai tanatológia iskolateremtő tudósának, Polcz Alaine-nek az írásai tartoznak. Az 1990-es évektől Kovácsné Török Zsuzsa szakkutatásai és közleményei jelentek meg a témában. A hazai szakirodalom legkurrensebbjei közé tartozik a 2008-ban közölt „Rossz hírek közlése” [2] címú Pilling-tanulmány, s ugyanezen szerző $A$ gyász [3] címet viselő kötete. A mai szakmai és praxisbéli, továbbá tudományelméleti téziseket és gyakorlati kérdéseket Zsák Éva és Hegedüs Katalin [4] összegzi, Berta Emese és szerzo"társa [5] az orvosok és rezidensek halálhírközlési traumáit elemzi, míg Zelena András a halálhír közlésének kommunikációs gesztusait mutatja be összegző tanulmányában [6]. Monostori Dóra és munkatársainak 2017-es közleménye a gyermekgyógyászati ellátás keretein belül hívja fel a figyelmet a perinatalis veszteségekben nyújtható gyásztámogatás intézményi lehetôségeire [7]. Fontos kiegészítése e bevezetőnek, hogy ma már a legtöbb honi orvosegyetem kurzushálójában szerepel kommunikációs készségeket tartalmazó tantárgy, s az Egészségügyi Közlöny egy 2011-es számában [8] megfogalmazott ajánlások segítik az ellátóteam tagjait a perinatalis veszteség esetén szükséges tennivalókban. Kiemelik azt is, hogy a segítő személy attitüdje képes minimalizálni a komplikált gyász veszélyét. Ehhez szükséges, hogy nyugodt környezetben, támogató hozzátartozó jelenlétében történjen a rossz hír közlése. Továbbá ajánlást fogalmaz meg a kommunikáció tartalmára vonatkozóan, így például arra is, hogy kerüljük a „lehet még másik gyermeke” vagy „az idő a legjobb gyógyszer” visszajelzéseket. Az ellátóteam tagjainak szóló ajánlás annak rögzítése is, hogy a gyors teherbe esés tanácsától óvakodjon a szakember, ugyanis a túlságosan korán vállalt terhesség meggátolja a gyászmunkát, kóros lelki folyamatokat indíthat el, és a később születendő gyermek esetében gyakoribbak a kötődési problémák, az anyai depresszió, szorongás előfordulása. A veszteség után ajánlott a pszichés támaszadás legalább 1-2 hónapig, majd a következő várandósság alatt a fokozott egészségügyi gondozás pszichés szegmensű kiegészítése.

\section{Módszertan}

A fenti szakirodalmakon kívül szúk a halálhírt követő szupportív lehetőségek kommunikációjának technikai és módszertani leírása, különös tekintettel arra, hogy hogyan, milyen protokoll szerint kell kommunikálni a hozzátartozóval. Ehelyett kórházigazgatói körlevelek, szervezeti és múködési szabályzatok részelemei, esetenként fekvőbeteg-intézmények belső protokolljai, s szerencsére egyre több orvosegyetemi kurzus tárgyalja e kérdéskört, valamint megjelentek az uniós finanszírozással megvalósuló projektek mellett a kommunikációs tréning- és kommunikációs coachingfolyamatok is.

Egy eset ismertetésével arra igyekszünk rávilágítani, hogy milyen fontos szerepe van az e szakaszban elhangzott vigasztalónak szánt mondatoknak és a közlést kísérő nonverbális jelzéseknek is. A tanulmányba emelt esetleírás praxisban szerzett tapasztalatokból származik, a Kemény István-i definíció szerinti 'mélyinterjú' során került rögzítésre. Az adatközlő édesanya történetének közléséhez szóbeli beleegyezését adta; az anonimitásra vonatkozó szabályok betartására ügyeltünk, valamint mind a helsinki, mind a tokiói egyezményt figyelembe vettük.

\section{Esetismertetés}

Kitti 43 éves, házasságban él, két nagyobb gyermek édesanyja. Szocioökonómiai státuszát jó anyagi körülmények, értelmiségi hivatás és vallásos szemlélet határozza meg. Fogadott orvosa volt egy fővárosi kórházban a terhesgondozásba vétel első pillanatától, s gondozott terhességének 37. hetében egészséges, tervezett és a család által várt újszülöttnek adott életet. A mindössze tizenegy napot élt újszülött az első vizsgálatokkor egészségesnek látszott, ám otthonába bocsátása napján testhője radikálisan megemelkedett, egy fertőzés következtében intenzív osztályra került, ahol légzéstámogatásra szorult. A gondos intenzív terápiás kezelés ellenére az osztályon töltött kilencedik napon elhunyt. Az anya szülészorvosa már a tragédia napján a betegágyhoz sietett, s az éppen a sokk gyászfázisába és állapotába kerülő anyával azt közölte, hogy „Sajnálom, de hiszen van már két egészséges gyermeke, s fél-háromnegyed év múlva akár újból teherbe eshet” - majd egy vigasztaló érintéssel távozott. A gyászoló anya későbbi elmondása szerint e találkozó és az ott elhangzott mondatok jelentése csak na- 
pokkal később vált felfoghatóvá és értelmezhetővé számára, a közlés pillanatában nem is értette, mi zajlik körülötte. A gyászoló anya a családtagjaival való, napokkal későbbi beszélgetés kapcsán hallotta ismét ugyanazon orvos vigasztalónak szánt mondatát, ám férjének címkézetten. Ez az ismételt közlés - férjének adresszáltan, de az ő jelenlétében - vált földolgozhatóvá számára. Saját elmondása szerint ekkor érezte a mondatok valódi súlyát. Mélyinterjú keretei között a gyászoló anya az érzelmi reakciók legszélesebb spektrumáról számolt be. Saját narratívája szerint: a „bénult tehetetlenséget önvád és magamba zuhanás" váltotta, majd az ellátóteam hibáztatása és Isten okolása következett a velük történtekért, végül pedig az amiatti bűntudat, hogy két nagyobb gyermekére nem figyelt eléggé a tragédiát követő ido”szakban.

A szerzők megállapítása, hogy számos tévhit kapcsolódik a veszteség feldolgozásához. „Az idő mindent megold" vigasztaló visszajelzés is ezek halmazát erősíti. Hiszen a gyászélmény és a hiánytapasztalat az idő múlásával radikálisan nem változik meg, ugyanis az idő múlása önmagában kevés; az a fontos, amit a gyászoló megtesz az eltelt idő alatt. A gyászmunka egyik fontos része tehát, hogy a negatív érzések túlsúlyba kerülése helyett az ellátóteam is bátorítsa a szomorúság és a fájdalom kifejezését. Ennek érdekében érdemes az érzelmek kifejezésében segíteni a gyászolókat, megtalálni azokat az érzéseket is, amelyek esetleg nem jutottak időben kifejezésre. A gyászolónak nincs szüksége tanácsra, azonban erősen szüksége van arra, hogy valaki meghallgassa, hogy valakinek el tudja mesélni anélkül, hogy ítélkezne vagy megkérdőjelezné az érzelmek jogosságát. Amennyiben ezt a lehetőséget nem kapja meg, úgy az elfojtott érzelmek akadályozni fogják a további lelki fejlődést, felépülést [9]. A perinatalis veszteséget súlyosbíthatja, hogy ebben az időszakban a testi-lelki szimbiózis miatt felerősödik a veszteség élménye, továbbá az önvád, bűntudat, harag érzése is jelenvaló. Az újszülött elvesztése sok esetben rombolja a szülők kompetenciaérzését, sérülhet a szülők jövőképe. Az anya pszichés és hormonális állapota váratlan és túlfokozott reakciókhoz, akár súlyos pszichés zavarok kialakulásához vezethet [10].

\section{Megbeszélés}

Mindannak ellenére, hogy Pilling János 2008-ban közölt "Rossz hírek közlése" [2] címú tanulmánya részletgazdagon tárgyalja a rossz hírek közlésének technikáját, alkalmazhatósági módszereit és azok prognosztizálható következményeit, úgy véljük, hogy az elvesztett gyermek meggyászolására időt kell biztosítani a szülőpár számára, s hagyni, hogy a gyászmunka elkezdődhessen. A gyász emocionális színterén csak a validált érzések feldolgozása tud megkezdődni; amennyiben ez a folyamat blokkolódik, az intellektuális és emocionális feldolgozási színterek késve tudnak egymásba érni, így lassítva, komplikálva a folyamatot. $\mathrm{S}$ ha nincsen orvosi ellenjavallata vagy aka- dálya annak, hogy a későbbiekben az anya egészséges gyermeknek adhasson életet, akkor sem szabad a „pótgyermek" víziójával enyhíteni fájdalmán. Ugyanis amikor a gyermek elvesztésének traumatikus hírével szembesül a szülő, akkor a sürgetett feldolgozás javaslatával olyan zavart okozunk, melynek következtében a későbbi feldolgozás a szokásos módon nem mehet végbe, s e zavar rögzül. Gyáni Gábor tárgyalja [11], hogy a traumát ideális esetben felváltja a gyászmunka és az átdolgozás. Ha viszont melankóliában és ismétlési kényszerben nyilvánul meg, akkor nem lesz megfelelő a feldolgozás, az érintett nem tud kilépni traumatizált helyzetéből, újraés újraéli ugyanazt a traumát, s nem jut el a gyászmunka következő állomásához, nem tud megbirkózni a folyamatosan halmozódó behatásokkal. Az átélt perinatalis veszteség a család egészére kihat, hatása hosszú távú. Apák esetében a hangulatzavar kevésbé intenzív, mint az édesanyáké. Az anyáknál a halálesetet követően normál pszichés reakció a depresszív hangulat, a feszültség érzése, az étkezési és alvási zavarok, valamint a halott gyermekkel kapcsolatos hallucinációk. Ezek a tünetek általában egy év alatt rendeződnek, azonban minden ötödik nőnél egy év után is megmaradnak, továbbá a veszteséget követő várandósság alatt a nők $20 \%$-ánál alakulhat ki a PTSD [12], amelyet az események újraélése, fokozott szorongás és büntudat érzése jellemez [13, 14].

E hatásokkal nem tudott mit kezdeni az esetleírásban szereplő anya, ugyanis kognitív disszonanciát okozott számára, hogy bár gyermekét gyászolja, az ellátóteam tagja mégis egy új élet reményével kecsegteti, s „pótgyermek" vállalására ösztönzi. A nemzetközi szakirodalom [15] számos kapcsolódó szaktanulmánya tárgyalja és elemzi annak kérdéskörét, hogy a gyászmunka állomásain át kell mennie a hozzátartozónak ahhoz, hogy a kapcsolat minősége átdolgozódjon, a gyászmunka a normál feldolgozási szakaszokon keresztül elvégződhessen. E folyamatban pedig az ellátóteam sürgetett feldolgozásra utaló mondatai és megnyilatkozásai traumatogén hatásúak. A perinatalis veszteség pedig pszichológiai szempontból különösen traumatizáló hatású, mivel az anya és az újszülött/magzat kapcsolata testi-lelki értelemben szoros, az érzelmek megélése intenzív, a veszteség általában hirtelen, váratlanul következik be. Ezen tényezők növelik a patológiás gyász előfordulását [11]. A patológiás gyász esetében a normális gyászreakciók elhúzódhatnak, 1-2 évvel a haláleset után is megfigyelhetők, további jellemzője az erős bűntudat, önvád, önsajnálat, apátia, szuicid fantáziák, hallucináció, deperszonalizáció, izoláció [16]. Esetismertetésünkkel arra a problémakörre szerettük volna felhívni a figyelmet, amely a gyásztámogató munka kapcsán állandóan viszszatérő kérdéskör. Nem egyszerú az ellátóteamben dolgozók helyzete, de minden nehézség ellenére napi munkánkban azt tapasztaljuk, hogy egyre többen és jobban kísérik a veszteséget átélő szülőket a gyász rendkívül nehéz időszakában. 


\section{Következtetések}

Fontos hangsúlyozni a konklúziók levonásakor a támaszadás jelentőségét, hiszen a nemzetközi szakirodalom rögzíti: az érzelmi szorongás és a kötődés elmaradásából eredő hiánytapasztalat a perinatalis veszteség után számos esetben tetten érhető, sokszor pedig ez a következő szülést követő mentális állapot rögzítésekor kerül csak felszínre [17]. A prae- és perinatalis veszteséghez kapcsolódó anyai attitűdökrôl és a gyermek elvesztéséhez kapcsolódó érzelmi viszonyulásról összegző megállapításokat találunk a Peppers-Knapp szerzőpáros kötetében [18], mely megállapítások jól alkalmazhatók a hazai ellátás keretrendszerében. Tanácsként azt tartjuk fontosnak rögzíteni, hogy a gyászoló szülőknek szükségük van arra, hogy valaki meghallgassa őket. Egy olyan személyre, akinek el tudják mesélni történetüket anélkül, hogy az ítélkezne felettük, esetleg megkérdőjelezné érzelmeik jogosságát, vagy bagatellizálná veszteségüket az alábbi mondatokkal: „van két egészséges gyermeke”, „nemsokára újra szülhet”. E hibás kommunikációs panelek és terminus technicusok helyett az együttérzést biztosító közös emlékezésnek (például 'memory box' összeállításával) van helye, valamint a szülő közléseinek-kérdéseinek kell teret biztosítani. Fontos felvázolnunk a segítő lehetőségeket mindamellett, hogy biztosítjuk a szülőket: mellettük állunk gyászukban. Jó gyakorlatként elhangozhat a 'Minket is mélyen érint', 'Ha gondolják, később is felkereshetnek' mondatok bármelyike.

Új utakat nyithat meg a hazai ellátás területén is annak a pillanatnak az elfogadott deklarálása, amely a neonatalis palliatív családgondozás irányába mutat. Nemcsak arról van szó tehát, hogy elemezni kezdjük az érintett család veszteségfeldolgozását nehezítő, hibás kommunikáció következményeit, hanem a fókusz már a családközpontúságra helyeződik. Ekképp a szülő partneri helyzetbe kerül, döntéshozatali folyamat részesévé válik. Ennek letéteményese pedig az individualizált, együttérző, a fájdalmas érzéseket legitimáló, támaszadó ellátás [19, 20].

Anyagi támogatás: A közlemény megírása és a kapcsolódó kutatómunka anyagi támogatásban nem részesült.

Szerzői munkamegosztás: M. D.: A módszertan, a megbeszélés, az összegzés és az irodalomjegyzék összeállítása. D. E.: A magyar nyelvű összefoglalás megírása, nemzetközi szakirodalom keresése. Z. A.: A bevezetés, esetismertetés megírása, tudományos kontroll. A cikk végleges változatát valamennyi szerző elolvasta és jóváhagyta.

Érdekeltségek: A szerzőknek nincsenek érdekeltségeik.

\section{Irodalom}

[1] Pilling J. The role of communication in preventing and managing supply failures. In: Baranyai Zs, Harsányi L. (eds.) Patient safety. [A kommunikáció szerepe az ellátási hibák megelőzésében és kezelésében. In: Baranyai Zs, Harsányi L. (szerk.) Betegbiz- tonság.] Medicina Könyvkiadó, Budapest, 2017; pp. 109-122. [Hungarian]

[2] Pilling J. Riporting bad news. In: Pilling J. (ed.) Medical communication. [Rossz hírek közlése. In: Pilling J. (szerk.) Orvosi kommunikáció.] Medicina Könyvkiadó, Budapest, 2008; pp. 306-334. [Hungarian]

[3] Pilling J. (ed.) The grief. [A gyász.] Medicina Könyvkiadó, Budapest, 2003. [Hungarian]

[4] Zsák É, Hegedűs K. Experiences of loss, grief, coping strategies in pre- and perinatal care. [Veszteségélmények, gyász, megküzdési stratégiák a prae- és perinatalis ellátásban.] Lege Artis Med. 2017; 27: 93-100. [Hungarian]

[5] Berta E, Zelena A. After-death communication problems, mentally trauma with it. [Orvosok, rezidensek halálhírközlési traumái a gyakorlatban.] Lege Artis Med. 2015; 25: 550-551. [Hungarian]

[6] Zelena A. Death notification as an act of communication. [A halálhír közlése mint kommunikációs gesztus.] Kharon, 2015; 19: 33-41. [Hungarian]

[7] Monostori D, Katona M, Tobak O, et al. Motherhood and grief, week by week (case study) - The process of grief counseling in the Perinatal Intensive Care Unit. [Anyaság, gyász hétról hétre (esetismertetés): Gyásztanácsadás folyamata a Perinatális Intenzív Centrumban.] Gyermekgyógyászat 2017; 68: 170-172. [Hungarian]

[8] The professional guidance of the Ministry of National Resources on psychological support regarding perinatal loss. [A Nemzeti Erőforrás Minisztérium szakmai irányelve a pszichológiai feladatokról szüléshez társuló veszteségek során.] Egészségügyi Közlöny 2011; 61: 357-369. [Hungarian]

[9] James JW, Friedman R. The Grief Recovery Handbook, 20th Anniversary Expanded Edition: The action program for moving beyond death, divorce, and other losses including health, career, and faith. Paperback. Harper-Collins Publishers, New York, NY, 2017.

[10] Kovácsné Török Zs, Szeverényi P, Forgács A. Perinatal grief reaction. [Perinatális gyászreakció.] Orv Hetil. 1994; 135: 18631867. [Hungarian]

[11] Gyáni G. Trauma, memory, cult. [Trauma, emlékezet, kultusz.] Élet és Irodalom 2006; 50: 6. [Hungarian]

[12] Tringer L. Textbook of psychiatry. [A pszichiátria tankönyve.] Semmelweis Kiadó, Budapest, 2005. [Hungarian]

[13] Hughes P, Riches S. Psychological aspects of perinatal loss. Curr Opin Obstet Gynecol. 2003; 15: 107-111.

[14] Barr P. Relation between grief and subsequent pregnancy status 13 months after perinatal bereavement. J Perinat Med. 2006; 34 : 207-211.

[15] Devan GS. Managent of grief. Singapore Med. J. 1993; 34: 445448.

[16] Kovácsné Török Zs, Szeverényi P, Hetey A-né. The psychological aspects of mourning, I. A process of mourning: normal and pathological mechanism. [A gyász pszichológiai vonatkozásai I. A gyász folyamata: a normál és a patológiás gyászmechanizmus.] Magy Pszichol Szle 1995; 51: 243-249. [Hungarian]

[17] Armstrong DS. Emotional distress and prenatal attachment in pregnancy after perinatal loss. J Nurs Scholarsh. 2002; 4: 339345.

[18] Peppers LG, Knapp RJ. Motherhood \& Mourning: Perinatal death. Praeger, New York, NY, 1980.

[19] Kenner C, Press J, Ryan D. Recommendations for palliative and bereavement care in the NICU: a family-centered integrative approach. J Perinatol. 2015; 35(Suppl 1): 19-23.

[20] Guidelines for health care professionals supporting families experiencing a perinatal loss. Paediatr Child Health 2001; 6: 469477.

(Zelena András dr., Budapest, Diósy Lajos u. 22-24., 1165 e-mail: dr.zelenaa@gmail.com) 